\title{
Scuttle flies (Diptera: Phoridae) from the canopies of ash trees in Norway, with six new species
}

\author{
R. Henry L. DISNEY \\ Department of Zoology, University of Cambridge, Cambridge CB2 3EJ, England; e-mail: rhld2@hermes.cam.ac.uk
}

\begin{abstract}
Phoridae obtained from canopies of ash trees include descriptions of the hitherto unknown female of Gymnophora winqvisti Disney and six new species: Megaselia aulaeae n. sp., M. hortenensis n. sp., M. sognensis n. sp., M. strynensis n. sp., M. vestfoldensis n. sp. and Triphleba brevicostalis n. sp.
\end{abstract}

Key words: scuttle flies, Gymnophora, Megaselia, Triphleba, Norway, new species

\section{INTRODUCTION}

Karl Thunes and colleagues have been exploring the insect faunas of tree canopies in Norway. The first dealt with the canopies of Scots pine (Pinus sylvestris L.) (Thunes et al. 2004), followed by those of the common oak (Quercus robur L.) (Disney 2015). Reported below are the scuttle flies (Diptera, Phoridae) from the latest project sampling the canopies of ash trees (Fagus sylvatica L.). The specimens were passed to Kaj Winqvist who identified 3 distinctive species (listed below). The remaining material was handed over to the identification to the author (RHLD).

\section{MATERIAL AND METHODS}

The specimens identified by Kaj Winqvist are deposited in University Museum of Bergen. The rest were sent in 70\% ethanol and then mounted on slides in Berlese Fluid (Disney 2001) and deposited in the University of Cambridge Museum of Zoology (UCMZ).

\section{RESULTS}

\section{Borophaga carinifrons (Zetterstedt)}

Material. Male, Norway, Vestfold, Horten, $59.3657^{\circ}$ N, $10.4603^{\circ}$ E, 11 Jul 2017, K. H. Thunes \& S. Skåtoy (1, University Museum of Bergen).

\section{Gymnophora arcuata (Meigen)}

Material. Male, Norway, Vestfold, Horten, $59.3655^{\circ}$ N, $10.4604^{\circ}$ E, 18 Jul 2018, J. Svetlik \& I. Borja (12, University Museum of Bergen).

Note. In the key to the species of the European Gymnophora Macquart (Disney 2017) G. perpropinqua Mostovski \& Michaelovskaya should have been grouped with G. arcuata (Meigen) as its notopleural ridge is pale. 


\section{Gymnophora winqvisti Disney}

(Figs 1-11)

The female was previously unknown. It is described below.

Female. Frons as Fig. 1. Postpedicels as Fig. 2. Palps as Fig. 3. Notopleuron as Fig. 4. Dorsal view of abdomen as Fig. 5. Tergite 7 as Fig. 6. Sternites 7 and 8 as Fig. 7. Furca as Fig. 8. Front tarsus as Fig. 9. Hind femur and tibia as Fig. 10. Basal section of wing as Fig. 11. Wing length $2.48 \mathrm{~mm}$. Costal index 0.47 . Costal ratios $5.11: 1.01: 1$. Haltere knob pale grayish white.

Diagnosis (female). The single lobe (Fig. 7), instead of the paired lobes of most species, at the rear of sternum 8 resembles G. forresteri Disney and G. quartomollis Schmitz, but the tergites 7 (Fig. 6) and sternite 7 (Fig. 7) differ from both these species.

Material. Male, Norway, Vestfold, Horten, Lat. 59.3654, Lon. 10.4611, 11 Jul 2017, K. H. Thunes \& S. Skätøy, (1, UCMZ, 39-93). Female, Sogn \& Fjord: Stryn, 61.8605N, 6.3404E, 15 Jul 2018, J. Svetlik \& L. Børjia (11, UCMZ, 39-93).

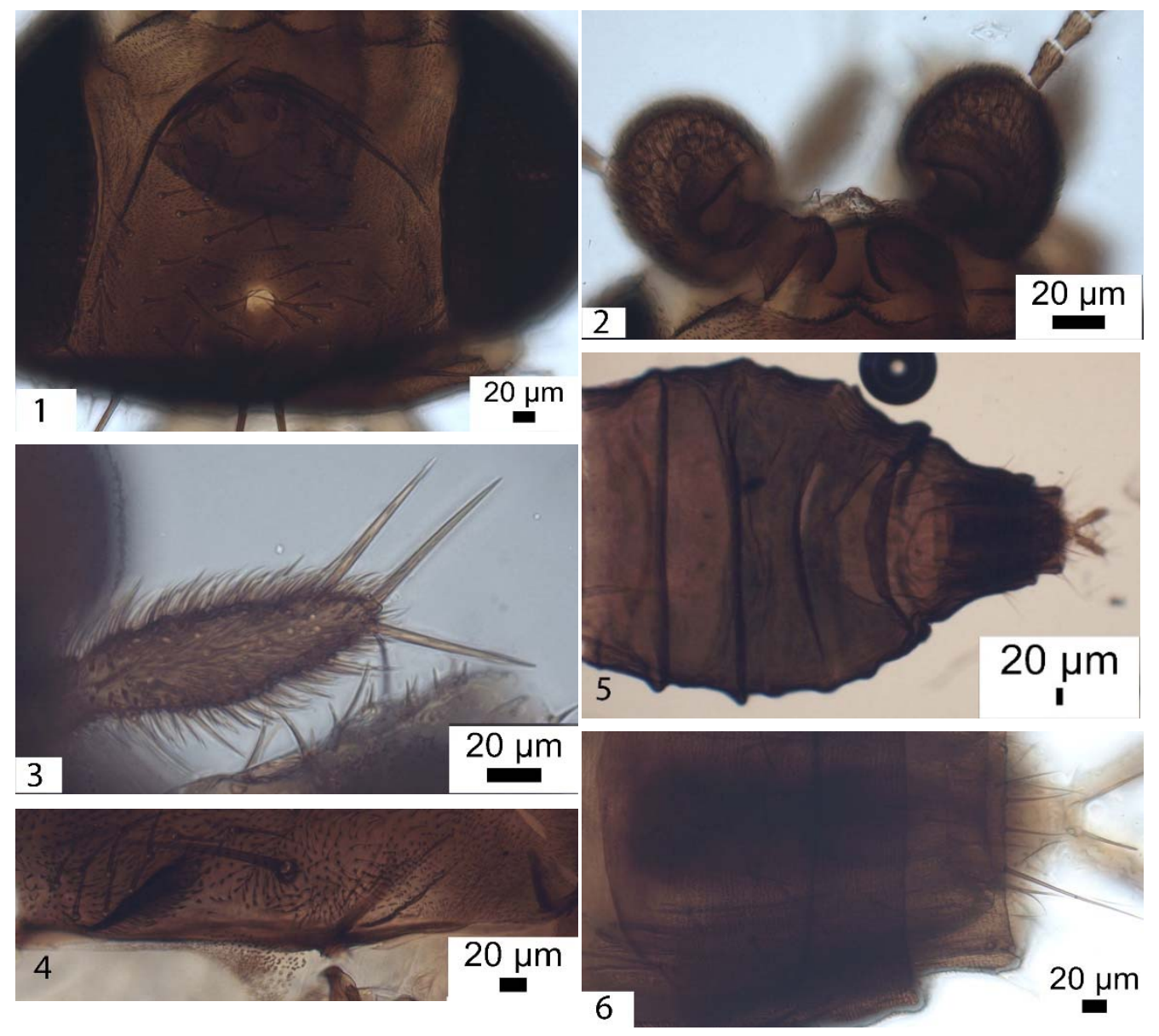

Figs 1-6. Gymnophora winqvisti Disney female. 1 - frons; 2 - postpedicels; 3 - palp; 4 - notopleuron; 5 - dorsal face of abdomen; 6 - tergite 7 . 


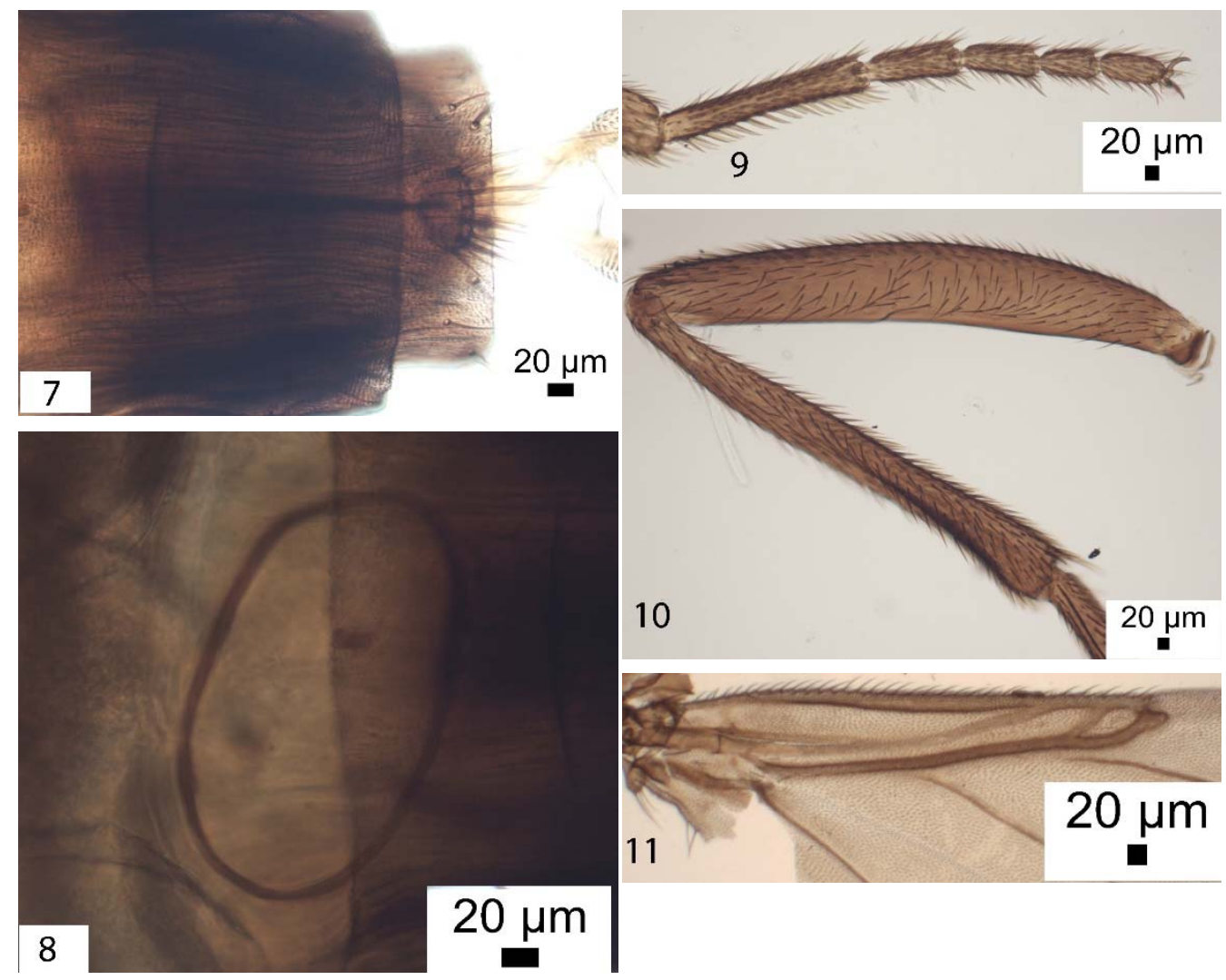

Figs 7-11. Gymnophora winqvisti Disney female. 7 - sternite 7 and rear of sternum $8 ; 8$ - furca; 9 - front tarsus; 10 hind femur and tibia; 11 - base of wing

\section{Megaselia angusta (Wood)}

Material. Male, Norway Sogn \& Fjord, Stryn, $61.8612^{\circ}$ N, $6.3370^{\circ}$ E, 15 Jul 2018, J. Svetlik \& L. Børjia (14, UCMZ, 39-92).

\section{Megaselia aulaeae n. sp.}

(Figs 12-23)

Diagnosis (male). In the key to the males of Megaselia from the British Isles (Disney 1989) it runs to couplet 58, where neither option applies. However in such a case one is directed to proceed to couplet 92, where the hairs at the base of the hind femur are intermediate, but the species of the first option have different hypopygia. The second option leads on to couplets 136139, but all options have different hypopygia, as also with an additional six species not covered. In the key of Schmitz (1957) to the Palaearctic species of Abteilung II it runs to couplet 31, where neither option fits. It likewise it fails to key out in Borgmeier's (1964) to Nearctic species of Group II; and likewise for the rest of the world fauna.

Male. Frons as Fig. 12, with very fine microtrichia mainly restricted to edges and by the median furrow. Cheek with 4 bristles and jowl with 2 that are much longer and more robust. Postpedicels, which lack SPS vesicles, palps and proboscis as Fig. 2. Thorax brown, with 3 

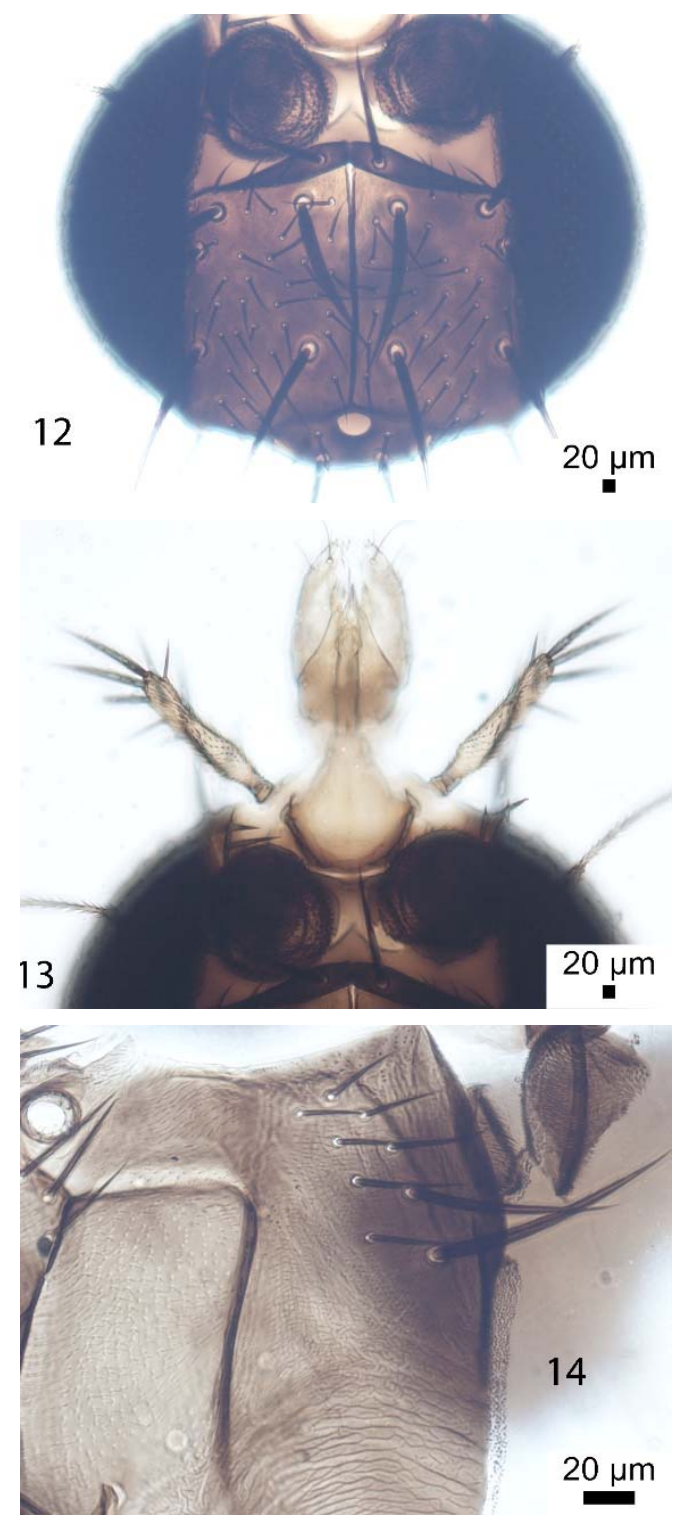
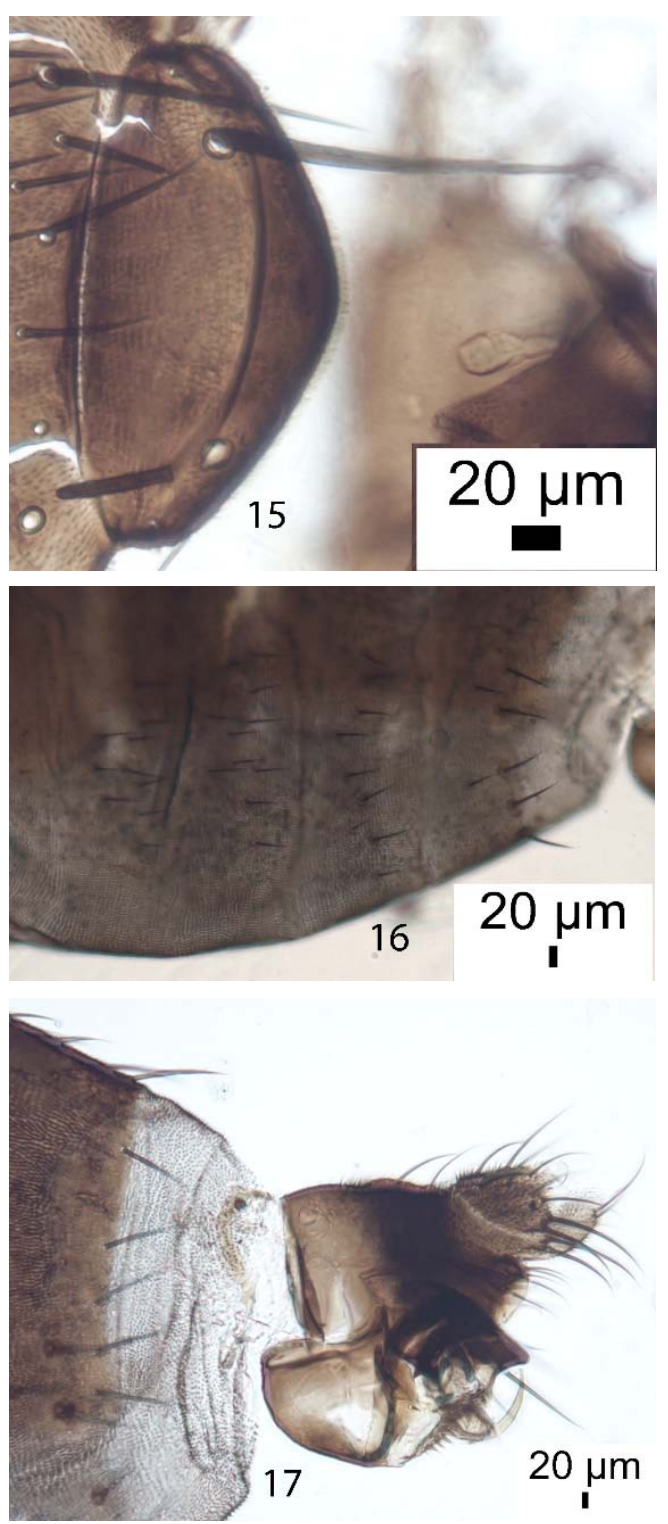

Figs 12-17. Megaselia aulaeae n. sp. male. 12 - frons; 13 - postpedicels, palps and proboscis; 14 - mesopleuron; 15 scvutellum; 16 - abdominal venter; 17 - left face of hypopygium.

notopleural bristles and no cleft in front of these. Mesopleuron with hairs and 2 bristles (Fig. 14). Scutellum with an anterior pair of small hairs and a posterior pair of bristles (Fig. 15). Abdominal tergites brown with small hairs except at rear of T6 (Fig. 17). Venter gray, and with hairs on segments 3-6 (Fig. 16). Hypopygium as Figs 17-19), the left hypandrial lobe with long microtrichia and as Fig. 18. Legs brown except front leg with tip of coxa, tibia and tarsi yellowish. Fore tarsus with posterodorsal hair palisade on segments $1-4$ and 5 clearly longer than 4 (Fig. 20). Dorsal hair palisade of mid tibia extends about 0.67 times its length. Hairs below basal half of hind femur longer than those of anteroventral row of outer half 
(Fig. 21), with those at base in 2 rows (Fig. 22). Hind tibia with about 20 only moderately differentiated posterodorsal hairs, without anterodorsals, and spinules of apical combs simple. Wings (Fig. 23) $1.33 \mathrm{~mm}$ long. Costal index 0.46. Costal cilia (of section 3) 0.09-0.10 mm long. No hair at base of vein 3.2 unequal axillary bristles, the outermost being $0.1 \mathrm{~mm}$ long. Sc not reaching R1. Haltere brown.

Material. Holotype male, Norway, Sogn \& Fjord, Stryn, $61.8613^{\circ} \mathrm{N}, 6.3367^{\circ} \mathrm{E}, 15 \mathrm{Jul} 2018$, J. Svetlik \& L. Børjia (16, UCMZ, 39-91).

Etymology. Named after it being from the canopy (aulaea) of an ash tree.

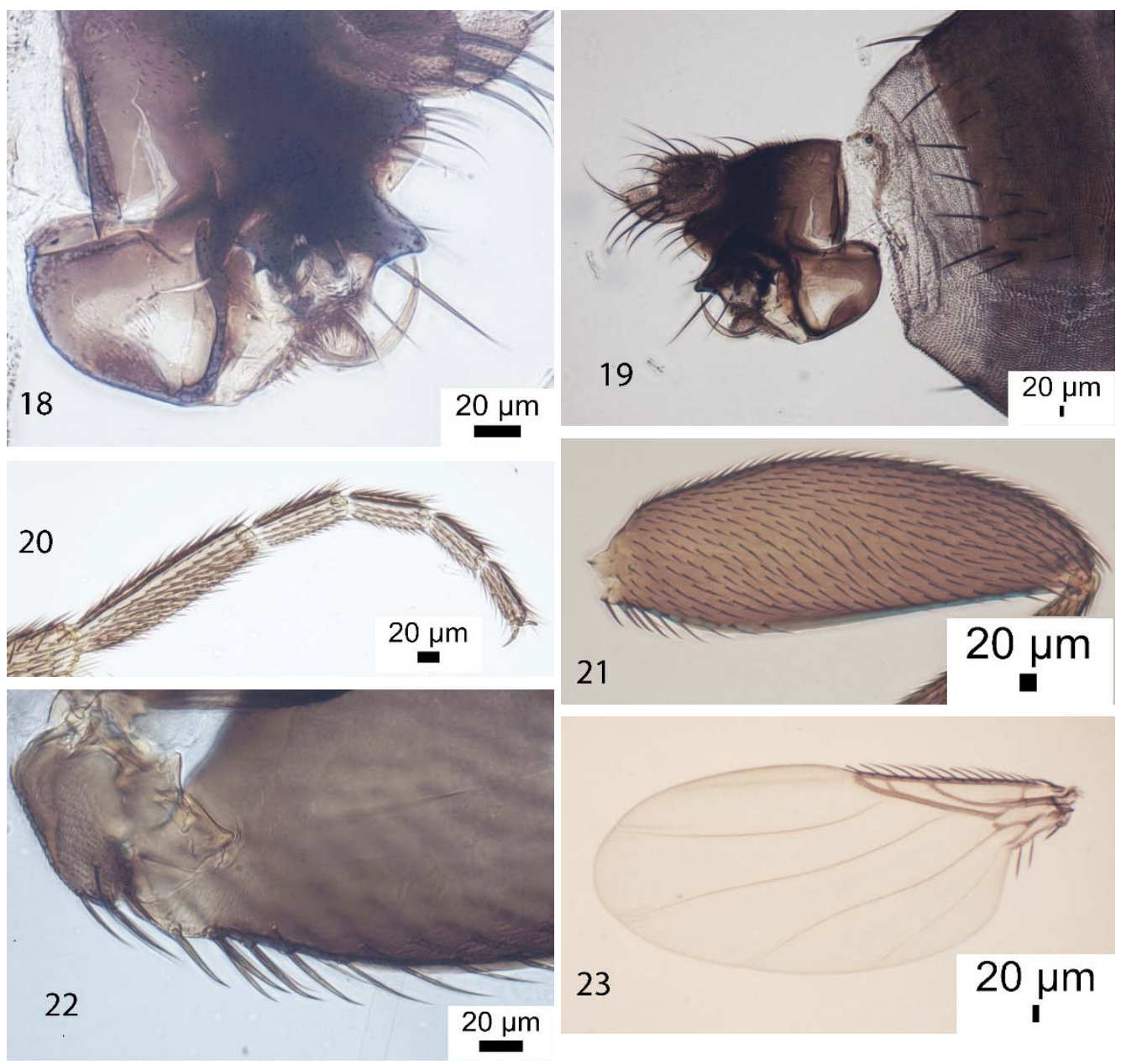

Figs 18-23. Megaselia aulaeae n. sp. male. 18 - left hypandrial lobe and penis complex; 19 - right face of hypopygium; 20 - front tarsus; 21 - hind femur; 22 - base of hind femur; 23 - wing.

\section{Megaselia buchsi Disney}

Material. Male, Norway, Sogn \& Fjord: Stryn, $61.8605^{\circ}$ N, $6.3401^{\circ}$ E, 15 Jul 2018, J. Svetlik \& L. Børjia (10, UCMZ, 39-91). 


\section{Megaselia drakei Disney}

Material. Male, Norway, Sogn \& Fjord: Stryn, $61.8605^{\circ}$ N, 6.3404 E, 15 Jul 2018, J. Svetlik \& L. Børjia (11, UCMZ, 39-93).

\section{Megaselia hortenensis n. sp.}

(Figs 24-35)

Diagnosis (male). Recognition. In the key to the males of Megaselia from the British Isles (Disney 1989) it runs to couplet 139, but its hyopygium clearly differs from both options. Six additional species run to the same couplet but the hypopygia of all differ as well as in other details such as the mesopleuron having a bristle as well as hairs and/or a longer costal index and/or more numerous axillary bristles, etc. In the key of Schmitz \& Delage (1974) to the Palaearctic species of Abteilung V it runs to couplet 15, but the hypopygia differ. In Borgmeier's (1964) key to Nearctic species of Group IV it runs to couplet 20 lead 1, but its hypopygium is different; and likewise for the rest of the world fauna.
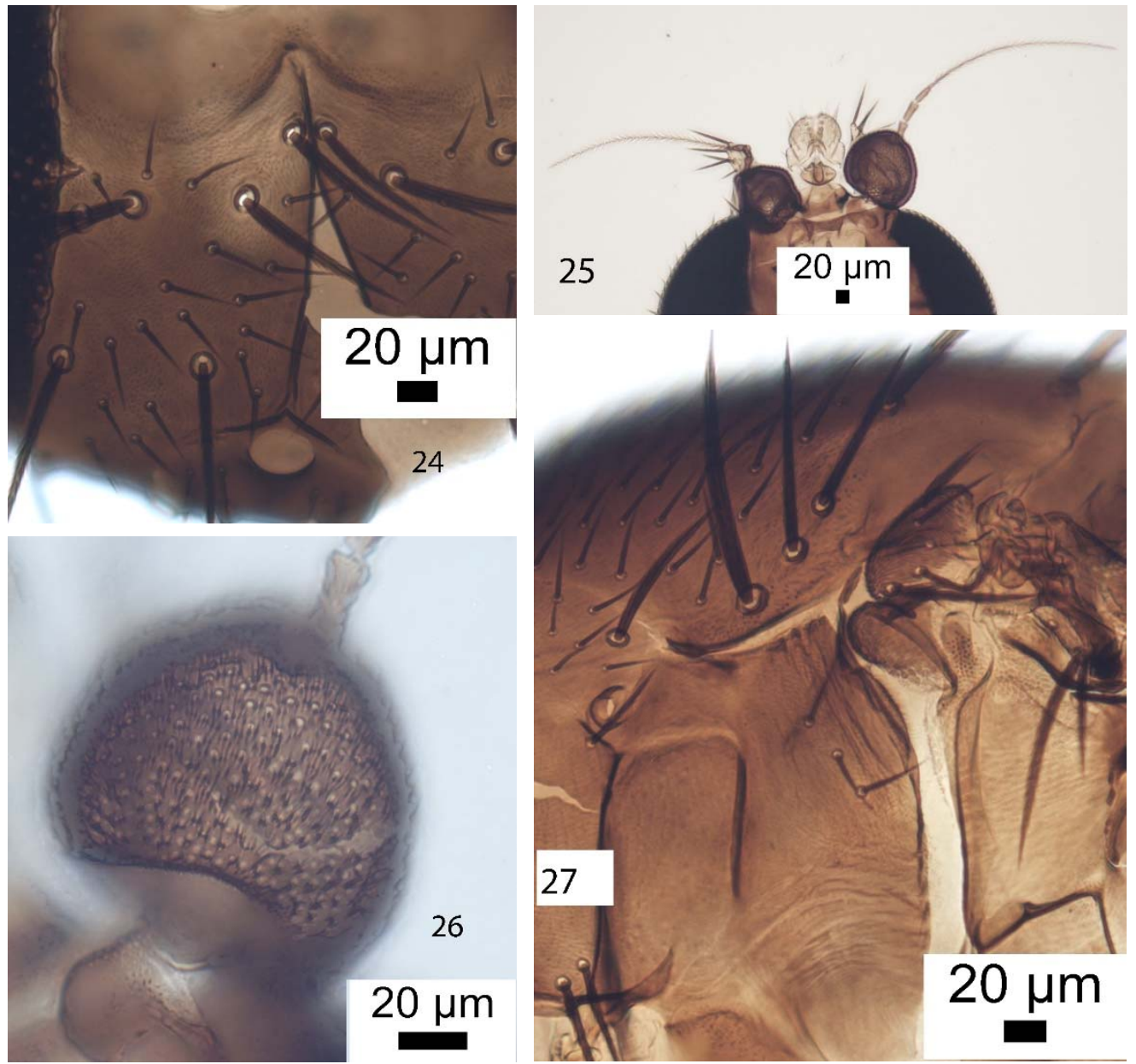

Figs 24-27. Megaselia hortenensis n. sp., male. 24 - frons; 25 - postpedicels, palps and proboscis; 26 - postpedicel; 27 - mesopleuron and notopleuron; 

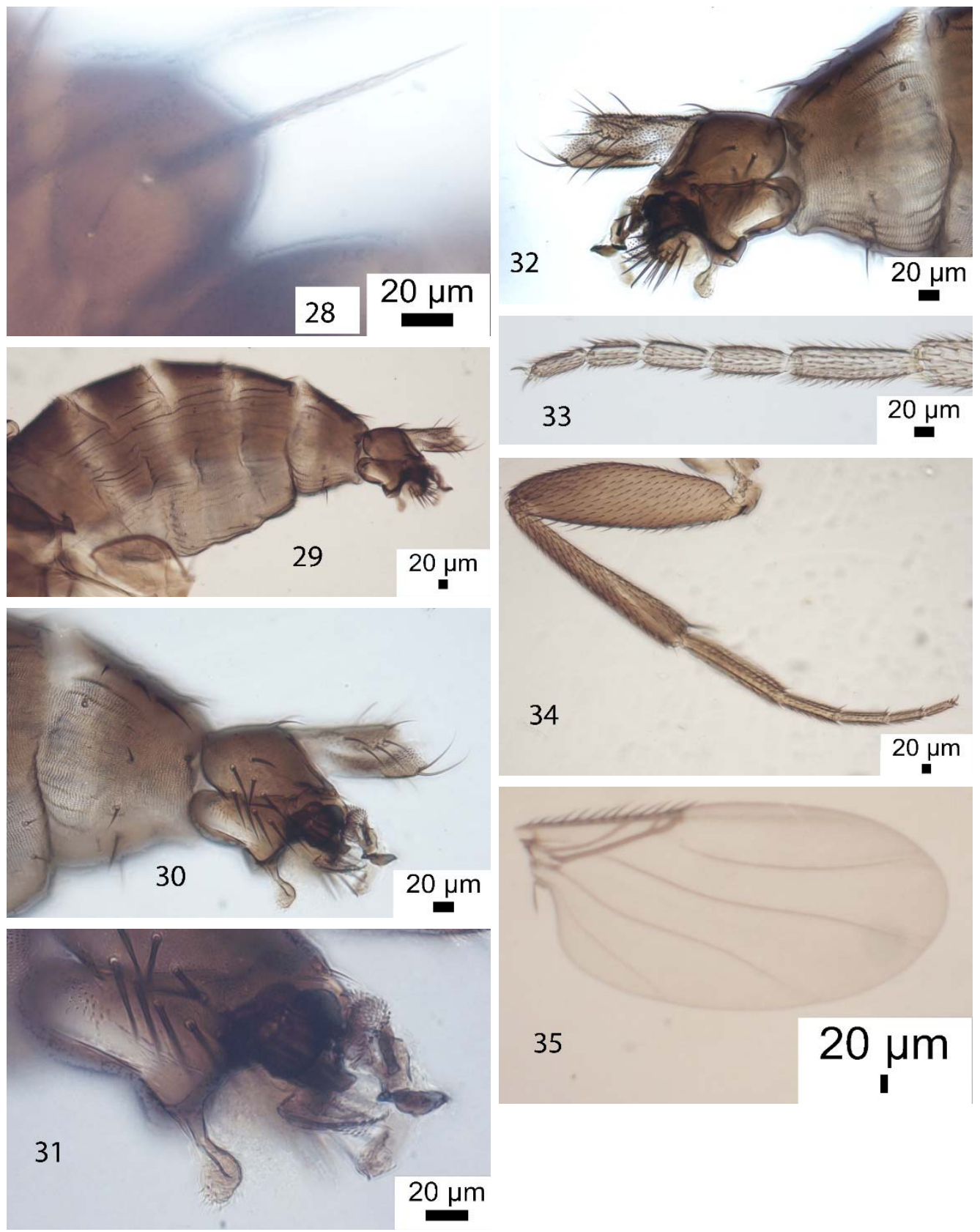

Figs 28-35. Megaselia hortenensis n. sp., male. 28 -scutellum; 29 - abdomen; 30 - left face of hypopygium; 31 - left face of hypandrium and penis complex; 32 - right face of hypopygium; 33 - front tarsus; 34 - hind leg; 35 - wing.

Male. Frons as Fig. 24, with dense but very fine microtrichia. Cheek with 3 bristles and jowl with 3 that are longer and more robust. Postpedicels (Fig. 26), without SPS vesicles, palps and proboscis as Fig. 25, the labella with only a few short spinules below. Thorax brown. Three notopleural bristles with no cleft in front of these mesopleuron with only 3 small hairs Fig. 27. 
Scutellum (Fig. 28) with an anterior pair of small hairs and a posterior pair of bristles. Abdominal tergites brown as Fig. Hypopygium as Figs 30-32. Legs dusky yellow to paler. Fore tarsus (Fig. 33) with posterodorsal hair palisade on segments $1-4$ and 5 clearly longer than 4 . Dorsal hair palisade of mid tibia extends about $0.62-0.63$ its length. Hind leg as Fig. 34, the hairs below the basal half of the femur being shorter than those of anteroventral row of outer half. Hind tibia with about 20 weakly differentiated posterodorsal hairs, without anterodorsals, and spinules of apical combs simple. Wings (Fig. 35)1.13-1.14 mm long. Costal index 0.39-0.42. Costal ratios 3.25-4.58:1.08-1.54:1. Costal cilia (of section 3) $0.7 \mathrm{~mm}$ long. No vein 3 hair. 2 unequal axillary bristles, the outermost being $0.07-0.09 \mathrm{~mm}$ long. Haltere brown.

Material. Holotype male, Norway, Vestfold, Horten, 59.3654º N, $10.4611^{\circ} \mathrm{E} ; 18 \mathrm{Jul} 2018$, J. Svetlik \& L. Børjia (9A, UCMZ, 39-93). Paratype male, as holotype except (6A) $59.3644^{\circ} \mathrm{N}$, $10.4605^{\circ} \mathrm{E}$.

Etymology. Named after Horten in which the type locality is situated.

\section{Megaselia jonasseni Disney \& Bøggild}

Material. Male, Norway, Sogn \& Fjord: Stryn, $61.8608^{\circ}$ N, $6.3395^{\circ}$ E, 12 Jul 2018, J. Svetlik \& L. Børjia (12, UCMZ, 39-92).

\section{Megaselia ruficornis (Meigen)}

Material. Male, Norway Vestfold, Horten, $59.3656^{\circ}$ N, $10.4606^{\circ}$ E; 18 Jul 2018, J. Svetlik \& L. Børjia (11A, UCMZ, 39-92).

\section{Megaselia sognensis n. sp.}

(Figs 36-43)

The single specimen is somewhat damaged.

Diagnosis (male). In the key to the males of Megaselia from the British Isles (Disney 1989) it runs to couplets 192, 193, 219 or 222 but its hypopygium differs from all the options. Likewise with 3 subsequently described species. In Borgmeier's (1964) key to Nearctic species of Group VII it fails to key out. Likewise for the rest of the world fauna.

Male. Frons (Fig. 36) with dense but very fine microtrichia. Cheek with 5 bristles and jowl with 3. Postpedicels, with many small spots but no SPS vesicles (Fig. 38), palps and proboscis as Fig. 37, the labella large and ventrally as Fig. 39. Thorax brown. 3 notopleural bristles and no cleft in front of these. Mesopleuron bare. Scutellum with an anterior pair of small hairs and a posterior pair of bristles. Abdominal tergites brown with small hairs that are only a little longer at rear of T6 and at most as long as those on epandrium, cerci and proctor, but those on the epandrium more robust than the rest. Anal tube about 1.3 times as long as the dorsal edge of the epandrium. Venter gray with hairs on segments 3-6 that are about as long as those at rear of T6. Hypandrium with posterior lobes vestigial and as Fig. 40. Legs yellowish brown to yellow. Front leg (Fig. 41) with posterodorsal hair palisade on segments $1-5$ and 5 clearly longer than 4. Dorsal hair palisade of mid tibia extends about 0.68 times its length. Hairs below basal half of hind femur longer than those of anteroventral row of outer half (Fig. 42). Hind tibia (Fig. 42 with a dozen differentiated posterodorsal hairs, without anterodorsals, and spinules of apical combs simple. Wings (Fig. 43) $1.96 \mathrm{~mm}$ long. Costal index 0.50. Costal ratios $2.82: 1.83: 1$. Costal cilia (of section 3) $0.15 \mathrm{~mm}$ long. Vein 3 hair $0.04 \mathrm{~mm}$ long. 3 axillary bristles, the outermost being $0.14 \mathrm{~mm}$ long. Vein Sc not reaching R1. Haltere knob pale (Fig. 44). 
Material. Holotype male, Norway, Sogn \& Fjord: Stryn, $61.8605^{\circ} \mathrm{N}, 6.3401^{\circ} \mathrm{E}, 12 \mathrm{Jul} 2018$, J. Svetlik \& L. Børjia (10, UCMZ, 39-91).

Etymology. Named after the type locality.
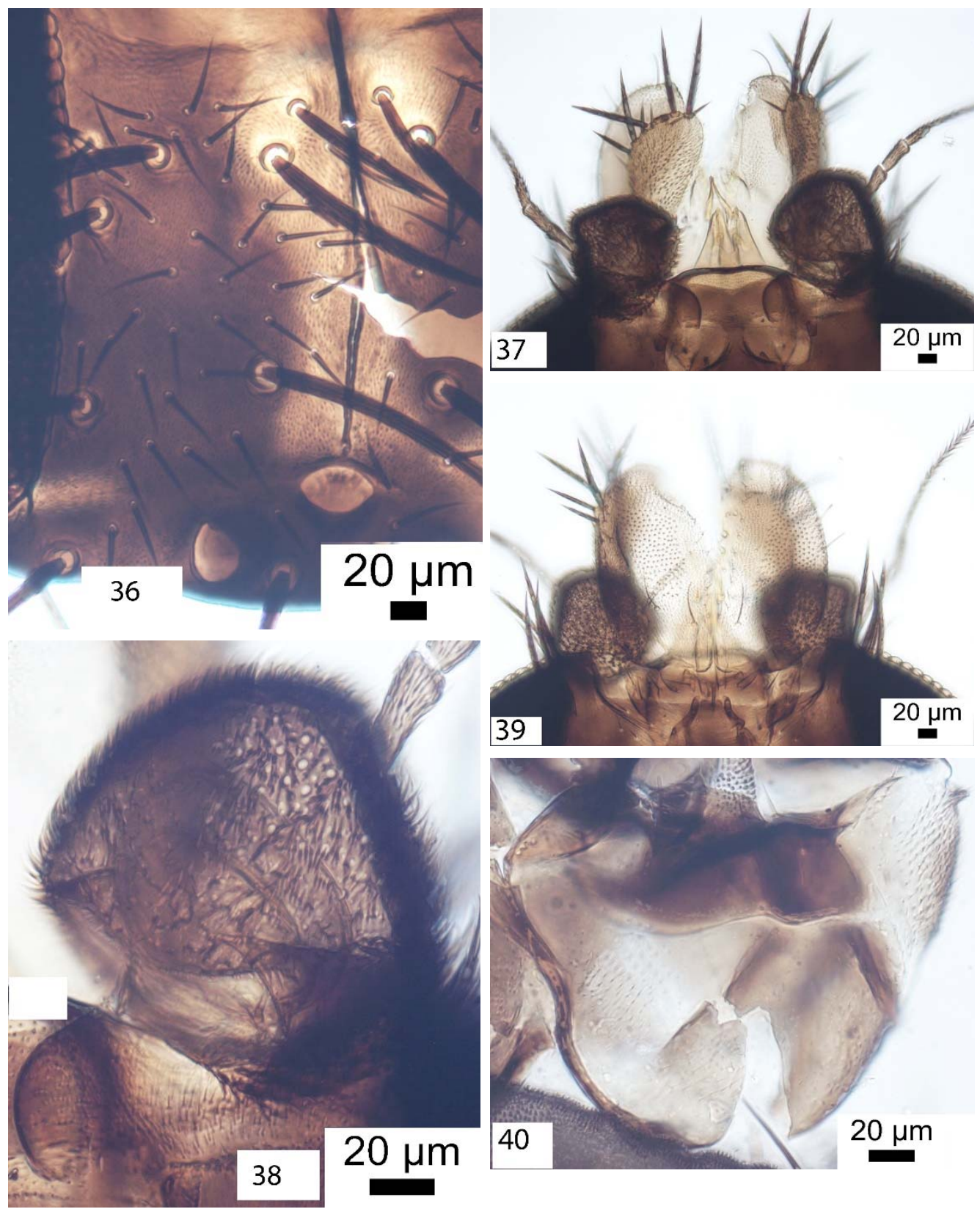

Figs 36-40. Megaselia sognensis n. sp. male. 36 - frons; 37 - postpedicels, palps and proboscis; 38 - postpedicel; 39 proboscis ventral view; 40 - hypandrium from below. 

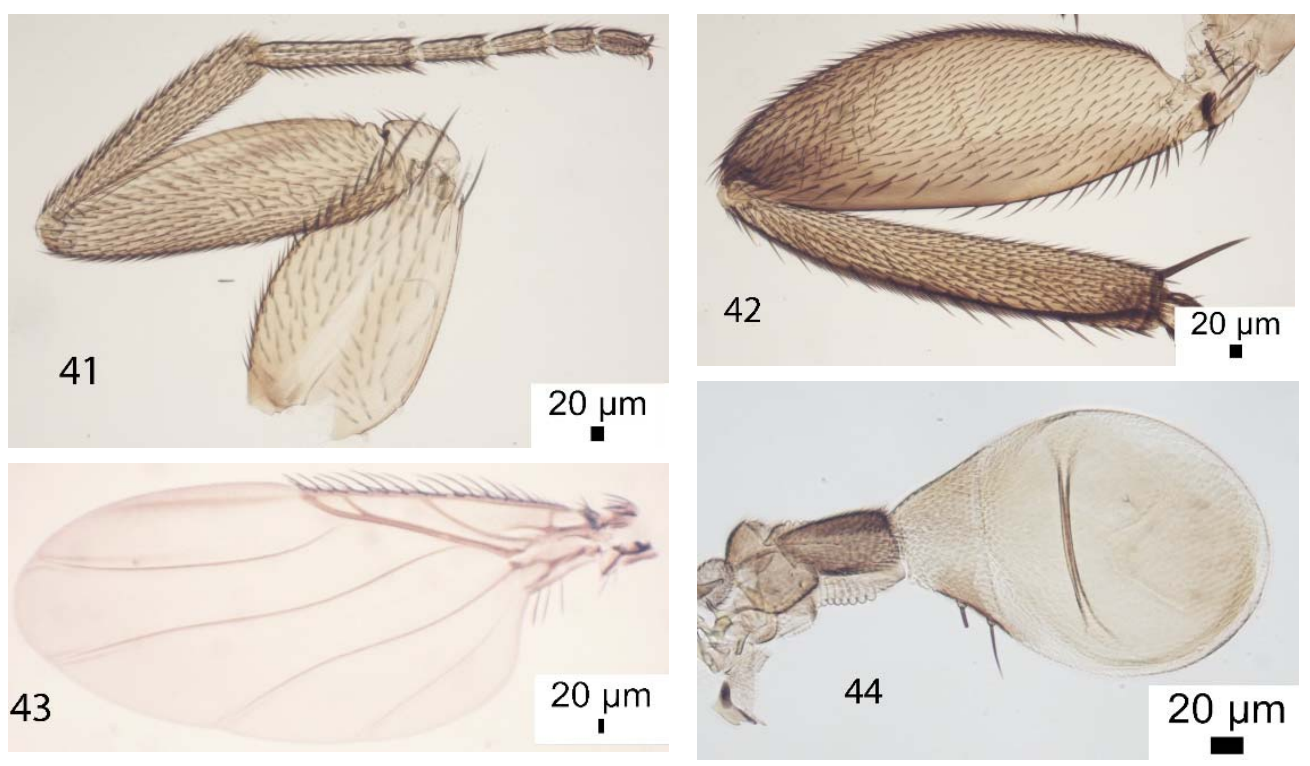

Figs 36-44. Megaselia sognensis n. sp. male. 41 - front leg; 42 - hind femur and tibia; 43 - wing; 44 - haltere.

\section{Megaselia strynensis n. sp.}

(Figs 45-56)

Diagnosis (male). In the key to the males of Megaselia from the British Isles (Disney 1989) it runs to couplet 167 where either lead applies as the feathering of the epandrial bristles is only discerned at high magnifications. Lead 1 takes one to couplet 173, where neither option fits. Lead 2 proceeds to couplet 176 lead 2, but the hypopygium differs. Taking lead 2 from couplet 167 one proceeds to couplet 232 lead 2 which returns one to couplet 171 and one may also return to couplet 192. The closest of these options is M. sheppardi Disney (at couplet 172), but apart from its hypopygium it has a dark brown thorax and abdominal tergites. From couplet 192 one returns to couplet 171. Additional species running to these points differ by their hypopygia apart from dark thorax and abdominal tergites. With the Nearctic species one needs to try Borgmeir's (1966) Group VII and Group VIII as the CI of 0.43 is too close to the division $<0.44$ or $>0.44$. With Group VII one runs to couplet 2, where the hypopygium doesn't fit; and with Group VIII one runs to couplet 4 , lead $1 \mathrm{M}$. decussata Borgmeir, but it has a yellow venter and a different brown hypopygium. It fails to key out for the rest of the world.

Male. Frons as Fig. 45 with dense but very fine microtrichia. Cheek with 2 bristles and jowl with 2 unequal bristles one of which is longer and more robust. Postpedicels, without SPS vesicles, palps and proboscis as Fig. 46. Thorax orange to yellow. 3 notopleural bristles with no cleft in front of these and mesopleuron bare (Fig. 47). Scutellum with an anterior pair of small hairs and a posterior of bristles (Fig. 48). Abdomen as Fig. 49, the venter with hairs on segments 3-6). Hypopygium as Figs 50-52) the epandrium having hairs and a pair of bristles each side. Left face of the hypandrium and penis complex as Fig. 51, the right lobe being vestigial. Right face of hypopygium as Fig. 53. All the Legs yellowish. Fore tarsus (Fig. 54) with posterodorsal hair palisades on segments 1-4 and 5 clearly longer than 4 . Dorsal hair palisade of mid tibia extends about 0.59 times its length. Hairs below basal half of hind femur longer than those of anteroventral row of outer half (Fig. 55). Hind tibia (Fig. 55) with 14-15 weakly differentiated posterodorsal hairs, without anterodorsals, and spinules of apical combs simple. Wings (Fig. 56 
$1.43 \mathrm{~mm}$ long. Costal index 0.43. Costal ratios $3.35: 1.74: 1$. Costal cilia (of section 3 ) $0.09 \mathrm{~mm}$ long. Vein 3 hair $0.01 \mathrm{~mm}$ long. 3 axillary bristles, the outermost being $0.10 \mathrm{~mm}$ long. Sc not reaching R1. Haltere as Fig. 48.

Material. Holotype male, Norway, Sogn \& Fjord: Stryn, $61.8605^{\circ} \mathrm{N}, 6.3404^{\circ}$ E, 15 Jul 2018 , J. Svetlik \& L. Børjia (11, UCMZ, 39-92-93).

Etymology. Named after the type locality.
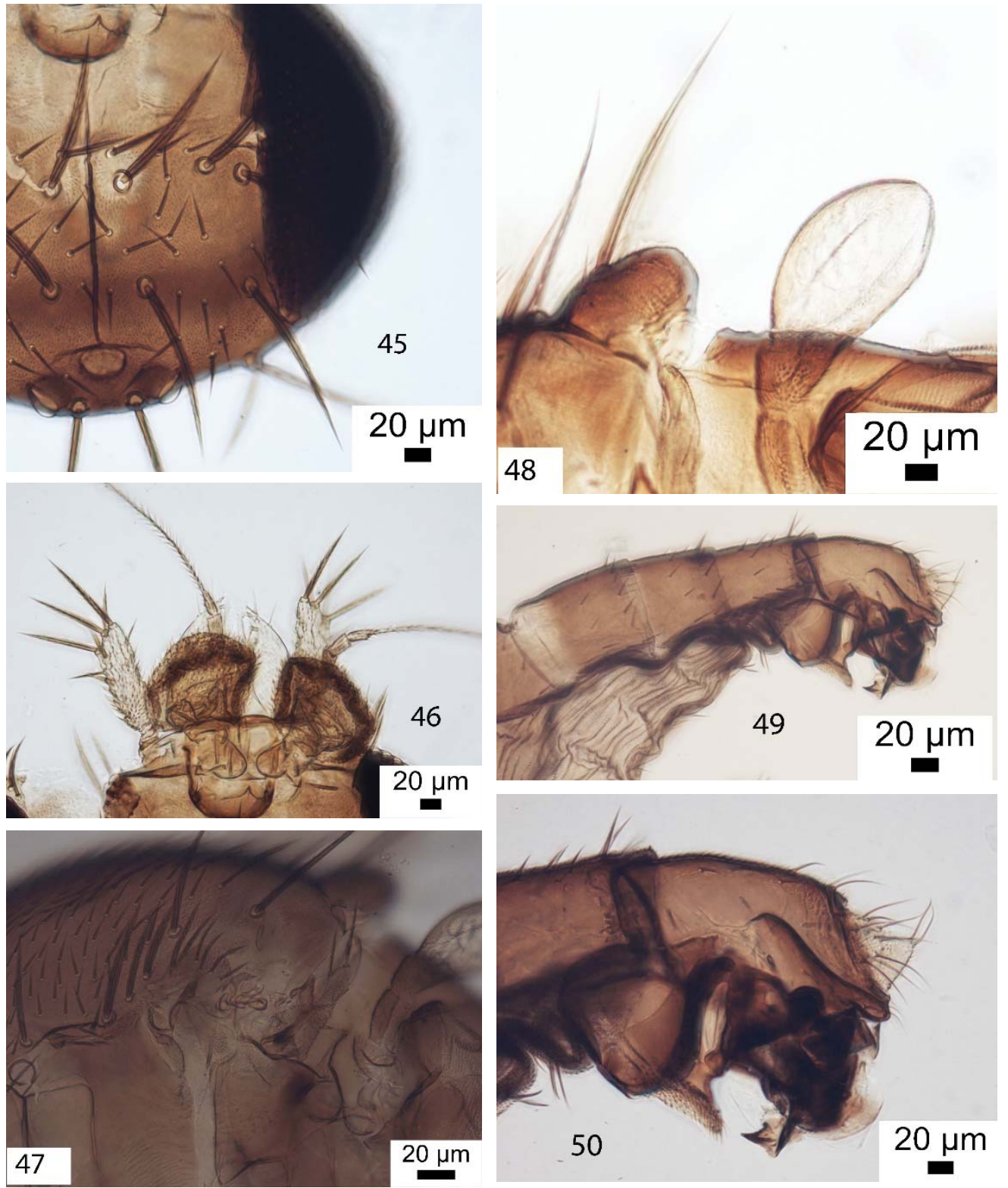

Figs 45-50. Megaselia strynensis n. sp. male. 45 - frons; 46 - postpedicels, palps and proboscis; 47 - mesopleuron and notopleuron; 48 - scutellum and haltere; 49 - left face of abdomen; 50 - left face of hypopygium. 


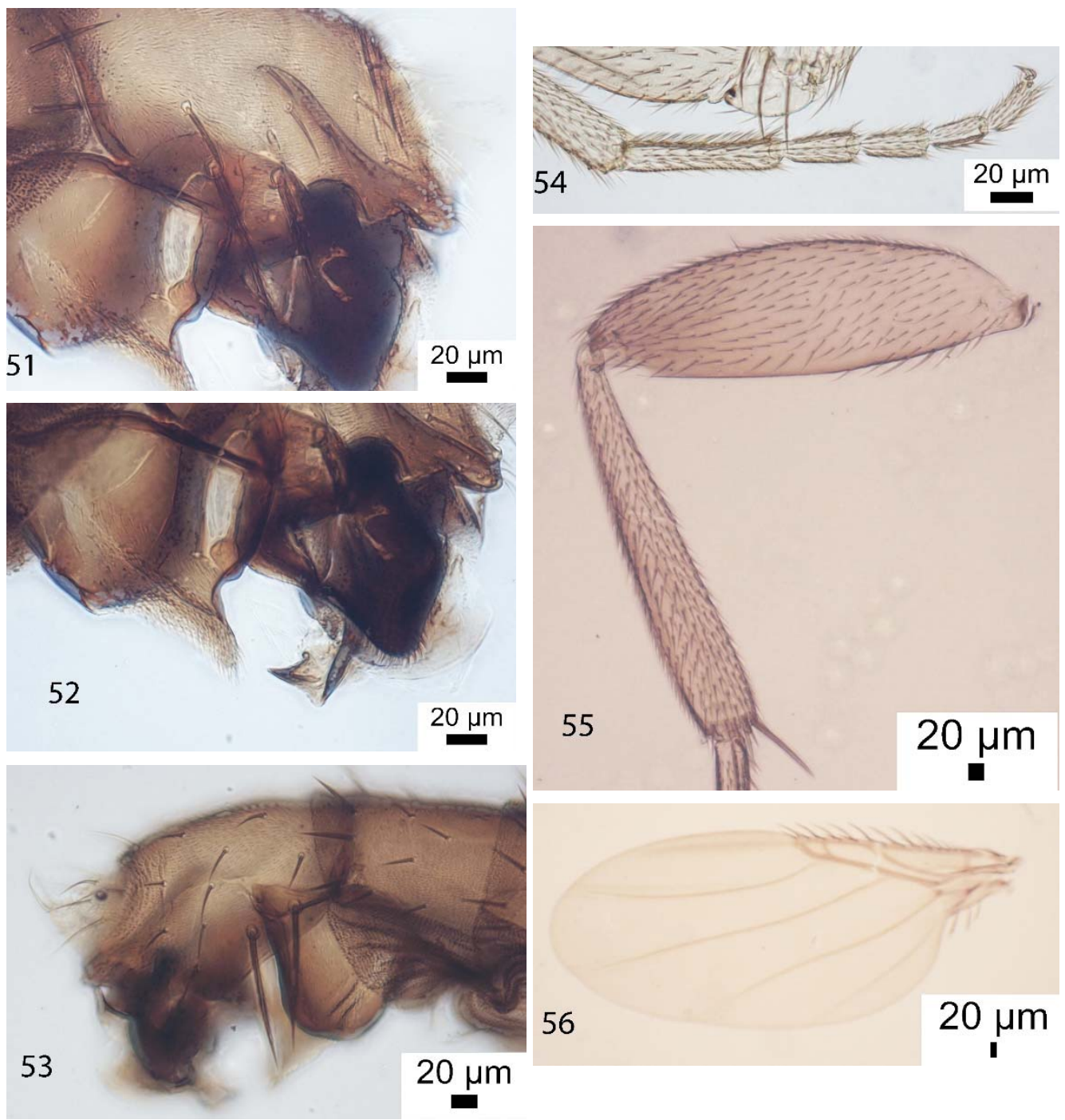

Figs 51-56. Megaselia strynensis n. sp. male. 51 - left face of lower half of epandrium; 52 - left face of hypandrium and penis complex; 53 - right face of hypopygium; 54 - front tarsus; 55 - hind femur and tibia; 56 - wing.

\section{Megaselia vestfoldensis n. sp.}

(Figs 57-65)

Diagnosis (male). In the key to the males of Megaselia from the British Isles (Disney 1989) it runs to couplet 214 then by a return loop to couplet 156 , where the hypopygium differs from both options. However, this group of species was revised by Buck \& Disney (2001). In their key it runs to couplet 7 lead 2 - undescribed species - at least 4 species requiring better specimens.

Male. Frons as Fig. 57, with very fine microtrichia but mainly towards the edges and next the median furrow. Cheek with 4 bristles and jowl with 2 that are much longer and 58, the postpediocels with numerous SPS vesicles. Thorax brown. Two notopleural bristles and a cleft 

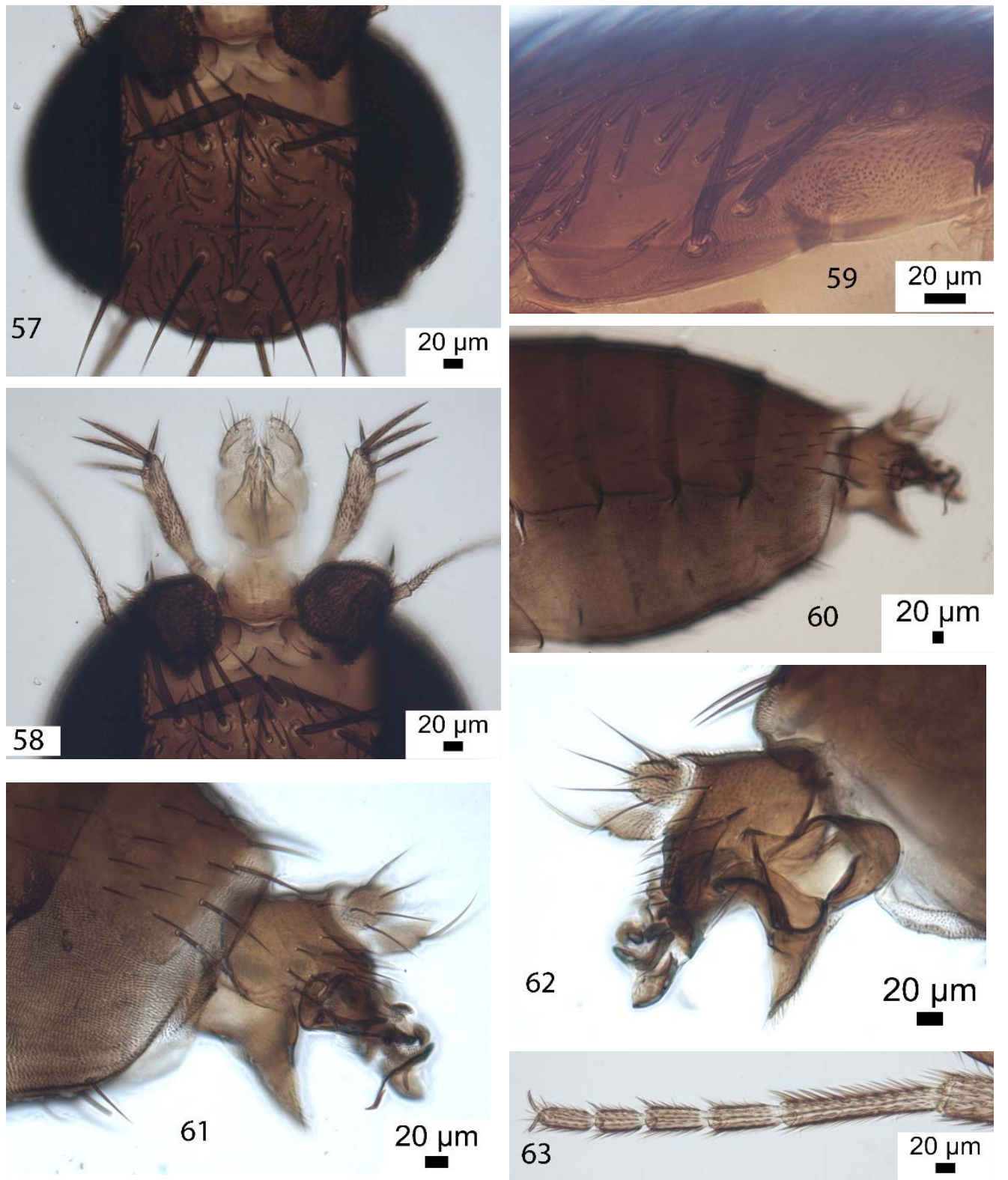

Figs 57-63. Megaselia vestfoldensis n. sp. male. 57 - frons; 58 - postpedicels, palps and proboscis; 59 - notopleuron; 60 - left face of abdomen; 61 - left face of hypopygium; 62, - right face of hypopygium; 63 - front tarsus.

in front of these (Fig. 59). Mesopleuron bare. Scutellum with an anterior pair of small hairs and a posterior pair of bristles. Abdominal tergites and venter as Fig. 60, the latter with hairs on segments 3-6. Hypopygium as Figs 61-62, the hypandrium lacking a right lobe. Legs brown. Fore tarsus with posterodorsal hair palisade on segments $1-4$ and 5 clearly longer than 4 (Fig. 61). Dorsal hair palisade of mid tibia extends about 0.79 times its length. Hairs below basal half of hind femur subequal to those of anteroventral row of outer half (Fig. 64. Hind tibia (Fig. 64) 
with a dozen differentiated posterodorsal robust bristles apart from the first 2-3 being more much finer, without anterodorsals, and spinules of apical combs simple. Wings (Fig. 65) $1.23 \mathrm{~mm}$ long. Costal index 0.41. Costal ratios $2.97: 1.40: 1$. Costal cilia (of section 3) $0.07 \mathrm{~mm}$ long. Vein 3 hair $0.06 \mathrm{~mm}$ long. 3 axillary bristles, the outermost being $0.09 \mathrm{~mm}$ long. Sc not reaching R1. Haltere pale whitish yellow.

Material. Holotype male, Norway, Vestfold, Horten, $59.3656^{\circ} \mathrm{N}, 10.4606^{\circ} \mathrm{E} ; 18 \mathrm{Jul} 2018$, J. Svetlik \& L. Børjia (11A, UCMZ, 39-92).

Etymology. Named after the type locality.

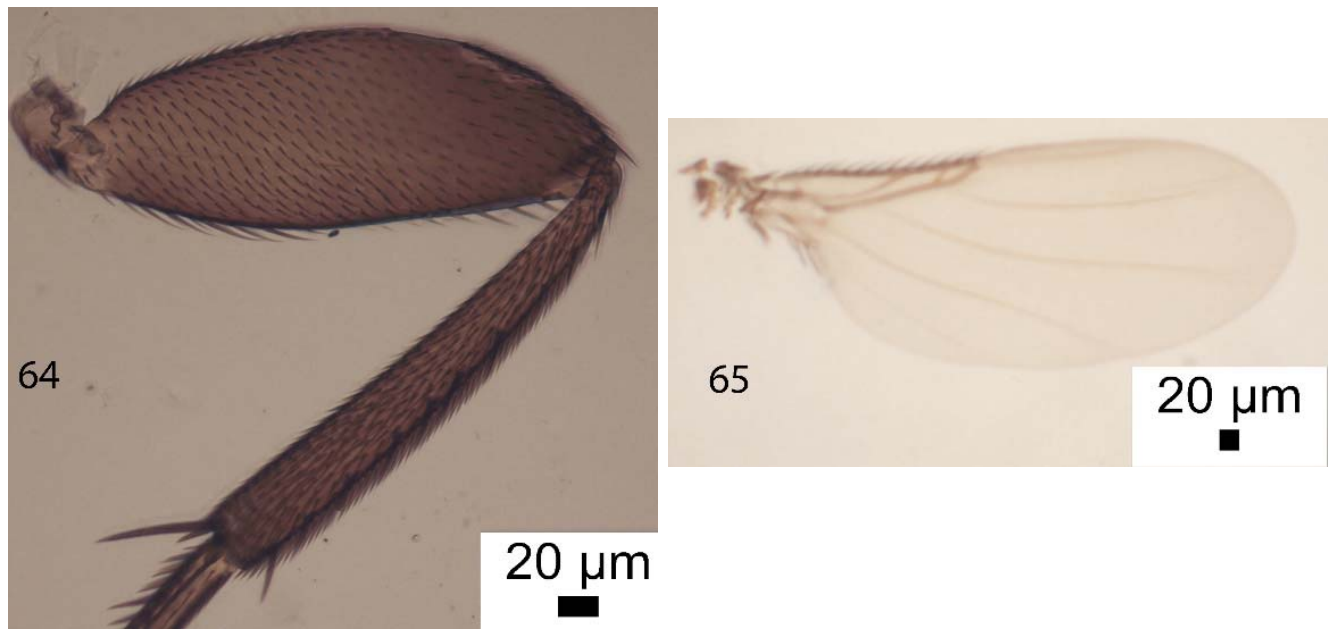

Figs 64-65. Megaselia vestfoldensis n. sp. male. 64 - hind femur and tibia; 65 - wing.

\section{Metopina galeata (Haliday)}

Material. Male, Norway, Vestfold, Horten, $59.3654^{\circ}$ N, $10.4611^{\circ}$ E; 18 Jul 2018, J. Svetlik \& L. Børjia (9A, UCMZ, 39-93).

\section{Triphleba brevicostalis n. sp.}

(Figs 66-76)

Diagnosis (female). The unforked vein 3 places this in the group of species previously assigned to the separate genus Citrago Sccmitz. Schmitz (1949). Delage \& Lauraire (1970) and Disney (1994) cover the males of the European species. Most are only known from the males. The costal index being clearly less than 0.50 immediately distinguishes this species from the rest of this species group.

Female. Frons as Fig. 66. Palps and proboscis as Fig. 67. Postpedicels dark brown and their lengths and breadths subequal (at about $0.11 \mathrm{~mm}$ ). Side of thorax as Fig. 68. Scutellum with an anterior pair of minute hairs and a posterior pair of long bristles. Abdominal tergites brown with small hairs (Fig. 69). Venter brown with hairs at rear of segment 6. Sternite 7 is seemingly absent (Fig. 70). Furca as Fig. 71. Sternum 8 and cerci as Fig. 72. The legs pale brown to yellowish. Front legs as Fig. 73, the tibia lacking an anterodorsal bristle. Mid tibia as Fig. 74, with one anterodorsal and 2 dorsal bristles. Hind femur and tibia as Fig. 75, the tibia with 1 anterodorsal bristle. The pale wing (Fig. 76) $1.70 \mathrm{~mm}$ long and with the costal index 0.44 and vein 3 lacking the anterior fork (vein 2) and costal section 1 is only slightly longer than 2 (1.05:1). Vein 7 not discernible. Halrtere brown (Fig. 68). 


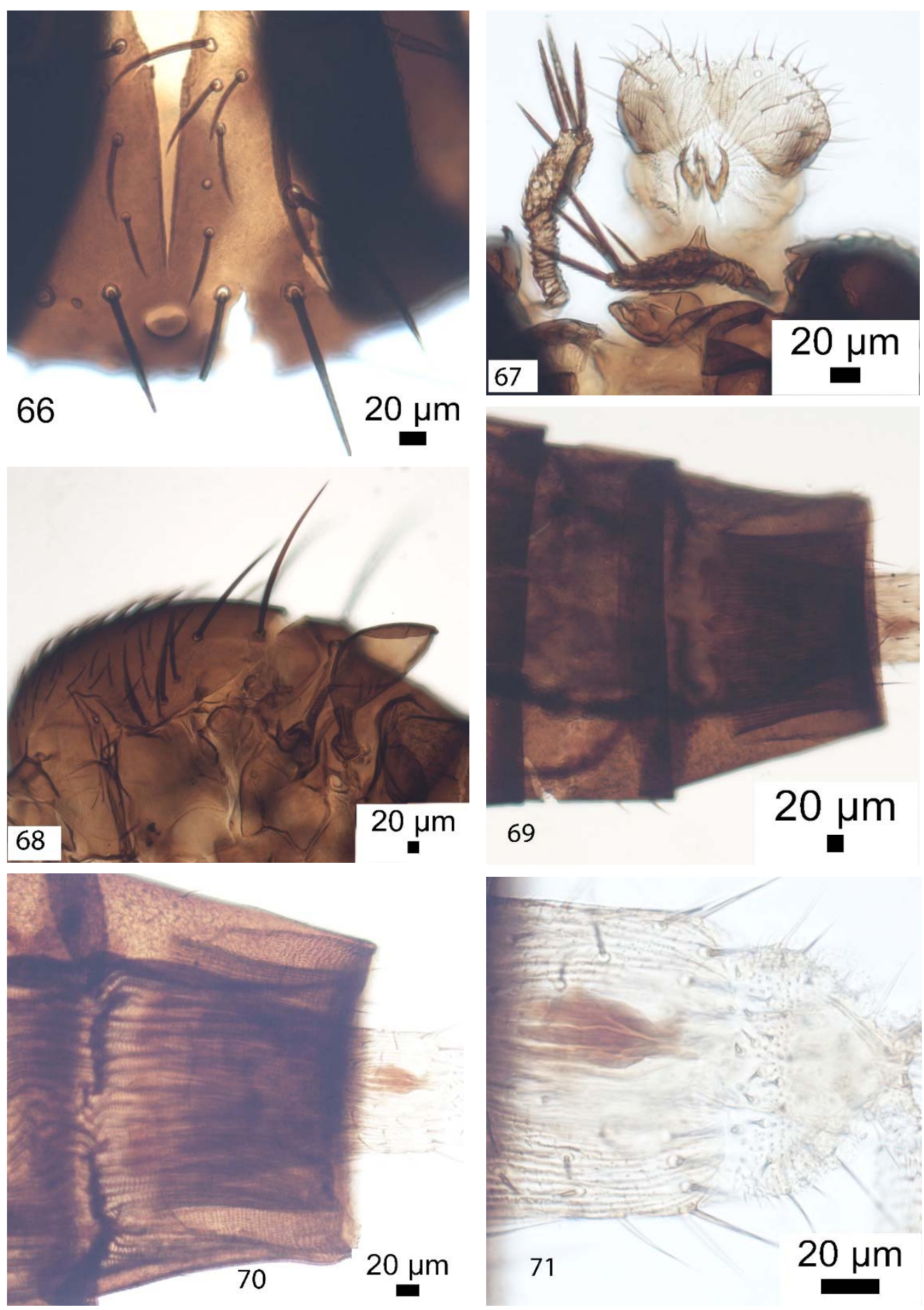

Figs 66-71. Triphleba brevicostalis female. 66 - frons; 67 - palps and proboscis; 68 - side of thorax; 69, abdominal tergites 5 and $6 ; 70$ - sternum $7 ; 71$ - furca. 

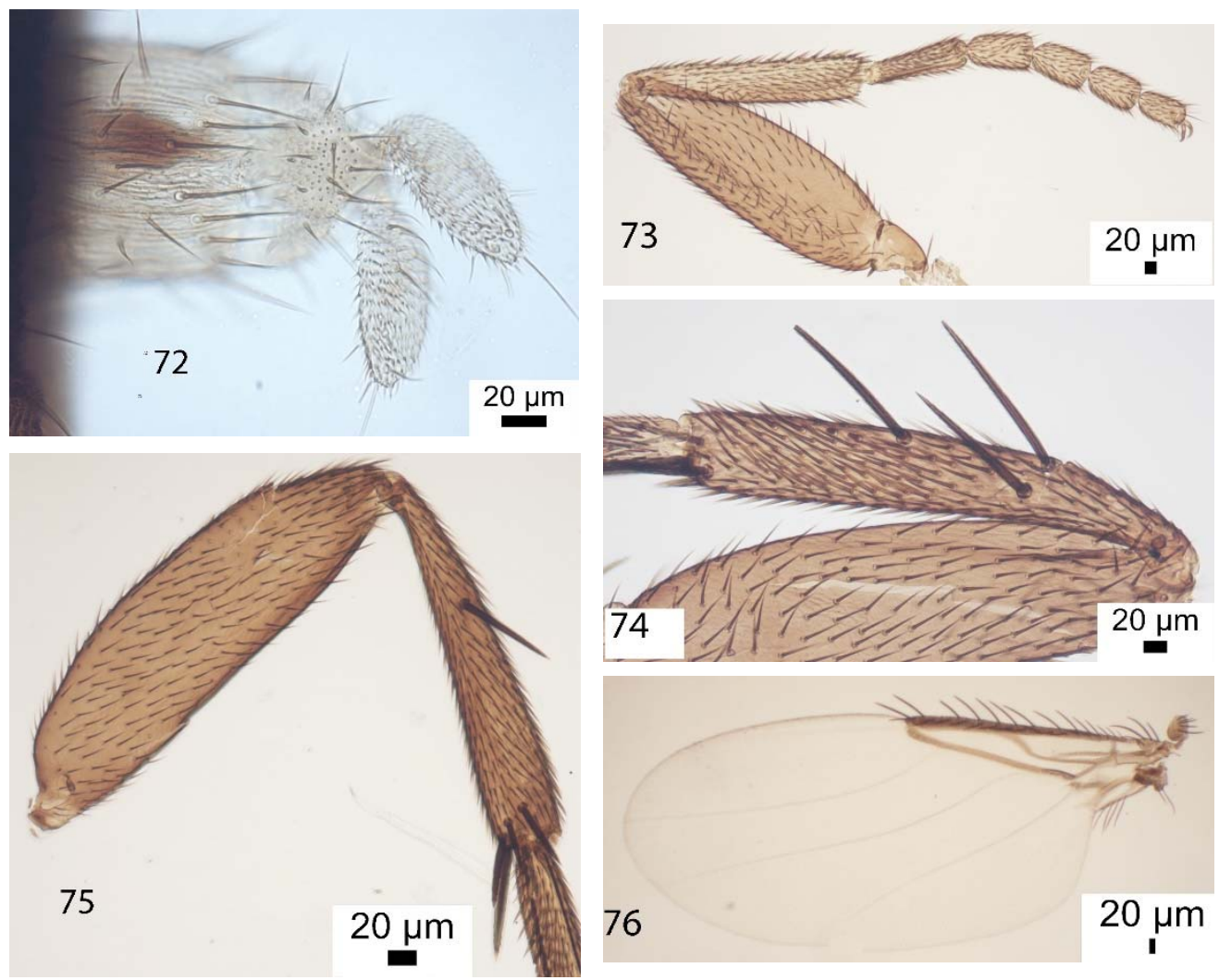

Figs 72-76. Triphleba brevicostalis female. 72 - sternum 8 and cerci; 73 - front leg; 74 - mid tibia; 75 - hind femur and tibia; 76 - wing.

Material. Holotype, female, Norway, Sogn \& Fjord: Stryn, $61.8605^{\circ} \mathrm{N}, 6.3404^{\circ} \mathrm{E}$, 15 Jul 2018, J. Svetlik \& L. Børjia (11, UCMZ, 39-93).

Etymology. Named after the short costal index.

\section{Triphleba subcompleta Schmitz}

Material. Male, Norway. Sogn \& Fjord: Stryn, $61.8605^{\circ}$ N, $6.3401^{\circ}$ E, 12 Jul 2018, J. Svetlik \& I. Borja (10, University Museum of Bergen).

\section{ACKNOWLEDGEMENTS}

My work on Phoridae is currently funded by the Balfour-Browne Trust (University of Cambridge).

\section{REFERENCES}

BorgmeIER T. 1964. Revision of the North American Phorid flies. Part II. The species of the genus Megaselia, subgenus Aphiochaeta (Diptera, Phoridae). Studia Entomologica, Petropolis 7: 257-416.

BorgmeIER T 1966. Revision of the North American Phorid flies. Part III. The species of the genus Megaselia, subgenus Megaselia (Diptera, Phoridae). Studia Entomologica, Petropolis 8: 1-160 (1965).

BuCK M. \& DisNeY R. H. L. 2001. Revision of the Megaselia giraudii and M. densior species complexes of Europe, including ecological notes (Diptera, Phoridae). Beiträge zur Entomologie 51: 73-154. 
Delage A. \& Lauraire M-C. 1970. Trois nouvelles espèces de Phoridae (Diptères, Brachycères, Cyclorrhaphes), trouvées à Peyresq (Alpes de Provence). Bulletin des Recherches Agronomiques de Gembloux 5: 450-458.

DisNey R. H. L. 1989. Scuttle Flies - Diptera Phoridae Genus Megaselia. Handbooks for the Identification of British Insects 10(8): 1-155. ISBN 0901546747.

DiSNEY R. H. L. 1994. A new species of Triphleba (Diptera: Phoridae) from France and the subfamily assignment of this genus. Giornale Italiano di Entomologia 6: 135-139 (1992).

DiSNEY R. H. L. 2001. The preservation of small Diptera. Entomologist's Monthly Magazine 137: 155-159.

DiSNEY R. H. L. 2015. Scuttle flies (Diptera: Phoridae) from the canopies of oak trees (Fagaceae) in Norway, including 13 new species. Norwegian Journal of Entomology 62: 20-52.

DiSNEY R. H. L. 2017. Systematic review of the European Gymnophora Macquart (Diptera: Phoridae), with five new species. Fragmenta Faunistica 60 (1): 23-46.

SChMitZ H. 1949. Phoridae. In: Lindner E (ed.), Die Fliegen der palaearktischen Region 4(33) (Lieferung 160): 193240. Stuttgart, E. Schweizerbart'sche Verlagsbuchhandlung.

Schmitz H. 1957. Phoridae. In: Lindner E (ed.), Die Fliegen der palaearktischen Region 4(33), (Lieferung 196): 417464. Stuttgart, E. Schweizerbart'sche Verlagsbuchhandlung.

Schmitz H. \& Delage, A. 1974. Phoridae. In: Lindner E (ed.), Die Fliegen der palaearktischen Region 4(33) (Lieferung 301): 638-664. Stuttgart, E. Schweizerbart'sche Verlagsbuchhandlung.

Thunes K. H., Thunes, K. H., Skartveit J., Gjerde I.; Stary J., Solhoy T., Fjellberg A., Kobro S., Nakahara S., zur Strassen R., Vierbergen G., Szadziewski R., Hagan D. V., Grogan W. L., Jonassen T., Aakra K., Anonby J., Greve L., Aukema B., Heller K., Michelsen V., Haenni J. P., Emeljanov A. F. Douwes P., Berggren K., Franzen J., Disney R. H. L. Prescher S., Johanson K. A., Mamaev B., Podenas S., Andersen S., Gaimari S. D., Nartshuk E.; Soli G. E. E., Papp L., Midtgaard F., Andersen A., von Tschirnhaus M., Bachli G., Olsen K. M., Olsvik H., Foldvari M., Raastad J. E., Hansen L. O., Djursvoll P. 2004. The arthropod community of Scots pine (Pinus sylvestris L.) canopies in Norway. Entomologica Fennica 15: 65-90.

\section{STRESZCZENIE}

\section{[Zadrowate (Diptera: Phoridae) z koron jesionów w Norwegii, z opisem sześciu nowych dla nauki gatunków]}

W pracy przedstawiono opisy sześciu, nowych dla nauki gatunków zadrowatych: Megaselia aulaeae n. sp., M. hortenensis n. sp., M. sognensis n. sp., M. strynensis n. sp., M. vestfoldensis n. sp. i Triphleba brevicostalis n. sp., a także opis nieznanej dotychczas samicy Gymnophora winqvisti Disney, Materiał Phoridae został zebrany z koron jesionów w Norwegii. 